\title{
Preliminary Viability Studies of Fibroblastic Cells Cultured on Microcrystalline and Nanocrystalline Diamonds Produced by Chemical Vapour Deposition Method
}

\author{
Ana Amélia Rodrigues ${ }^{\mathrm{a} *}$, Vitor Baranauskas ${ }^{\mathrm{b}}$, Helder Jose Ceragioli ${ }^{\mathrm{b}}$, Alfredo Carlos Peterlevitz, \\ Arnaldo Rodrigues dos Santos Junior ${ }^{c}$, William Dias Belangero ${ }^{\mathrm{a}}$ \\ ${ }^{a}$ Orthopaedic Biomaterials Laboratory, School of Medical Sciences, University of Campinas - UNICAMP, \\ CEP 13083-887, Campinas, SP, Brazil \\ ${ }^{\mathrm{b}}$ Department of Semiconductors, Instruments and Photonics, School of Electrical and Computer Engineering, \\ University of Campinas - UNICAMP, CEP 13083-970, Campinas, SP, Brazil \\ ${ }^{\mathrm{c}}$ Centre of Natural and Human Sciences, Federal University of $A B C-U F A B C$, \\ CEP 09090-400, Santo André, SP, Brazil
}

Received: February 7, 2012; Revised: September 25, 2012

\begin{abstract}
Implant materials used in orthopedics surgery have demonstrated some disadvantages, such as metallic corrosion processes, generation of wear particles, inflammation reactions and bone reabsorption in the implant region. The diamond produced through hot-filament chemical vapour deposition method is a new potential biomedical material due to its chemical inertness, extreme hardness and low coefficient of friction. In the present study we analysis two samples: the microcrystalline diamond and the nanocrystalline diamond. The aim of this study was to evaluate the surface properties of the diamond samples by scanning electron microscopy, Raman spectroscopy and atomic force microscopy. Cell viability and morphology were assessed using thiazolyl blue tetrazolium bromide, cytochemical assay and scanning electron microscopy, respectively. The results revealed that the two samples did not interfere in the cell viability, however the proliferation of fibroblasts cells observed was comparatively higher with the nanocrystalline diamond.
\end{abstract}

Keywords: biomaterials, culture cell, CVD diamond, implants

\section{Introduction}

All implants intended for use in the human locomotive system must be resistant to corrosion, fatigue and wear. Studies aimed at developing new materials and tests for biocompatibility are common in literature and are needed to evaluate the behavior of the material in contact with internal environment, the fluid and cellular components that will interact with the bone implant interface ${ }^{1,2}$.

Currently, aluminum-titanium-vanadium, titanium aluminum niobium, titanium and molybdenum alloys are used during clinical practice due to the excellent combination of biomechanical properties and resistance to corrosion that these materials present ${ }^{3,4}$. However, numerous studies in vivo and in vitro, suggest that degraded products released by these alloys trigger inflammatory processes that cause damage to adjacent tissues ${ }^{4-6}$.

Similarly alloy steels such as cobalt-chromium, cobalt-chromium-molybdenum and ceramics release degraded products causing an increase in the amount of inflammatory mediators responsible for bone reabsorption and therefore, leading to unfastening and loosening of prostheses ${ }^{7}$.

These alloys, consisting of nickel, cobalt, chromium, tantalum, titanium and vanadium, when in contact with the

*e-mail: labimo@fcm.unicamp.br biological system suffer corrosion and release metal ions reducing the service life of the implant ${ }^{7-9}$. Studies in vivo and in vitro demonstrated that these ions can be found in various parts of the body causing depression of specific cellular activity, local and systemic hypersensitivity, and activation of the inflammatory cascade ${ }^{10,11}$. Furthermore, these ions are increasingly associated with the development of malignant neoplasms in animal models ${ }^{12}$.

There is therefore a need to get more inert material when in contact with the internal environment. The diamond obtained through hot-filament chemical vapour deposition method (HFCVD) presents extreme hardness, a high thermal conductivity, a low coefficient of friction and chemical inertia, characteristics that can be used in the manufacturing of orthopedic implants ${ }^{13,14}$.

The purpose of this study was to characterize the microcrystalline diamond (MD) and nanocrystalline diamond (ND) by scanning electron microscopy (SEM), Raman spectroscopy and atomic force microscopy (AFM) and to analyze the behavior of samples during culture of Vero fibroblast-type cells, using cell viability tests (MTT assay and cytochemical analysis) and SEM to assess cell morphology. 


\section{Material and Methods}

\subsection{Preparation and characterization of the microcrystalline and nanocrystalline diamond}

Two diamond samples were produced by HFCVD method: MD diluted in hydrogen and ND diluted in hydrogen with $65 \%$ of Argon. The surface topography of MD and ND was viewed and photographed with a JEOL 5800 SEM. Raman spectra were acquired using the Renishaw Model in Via Raman microscope. MD spectra were obtained using a helium-neon laser at a wavelength of $633 \mathrm{~nm}, 2 \mu \mathrm{m}$ spot size and a power of $8 \mathrm{~mW}$. ND spectra were obtained with an argon laser at a wavelength of $514 \mathrm{~nm}$, spot size of $2 \mu \mathrm{m}$ and power of $6 \mathrm{~mW}$.

AFM imaging and roughness average $(\mathrm{Ra})$ measurements of the MD and ND surface morphologies were measured by AFM AutoProbe CP Park Scientific Instruments using silicon pyramidal tips operating in non-contact mode and a resonance frequency of $157 \mathrm{kHz}$. Representative surface scans $\left(20 \times 20 \mu \mathrm{m}^{2}\right.$ each $)$ at three different locations were obtained for MD and ND samples.

\subsection{Fibroblast cell cultures}

Fibroblastic cells are recommended for studies of cytotoxicity and cell-substratum interactions in biomaterial ${ }^{15}$. The Vero fibroblast-type cells used were obtained from the Adolfo Lutz Institute, São Paulo, Brazil. The cells were cultivated in F10 Ham medium (Nutricell) supplemented with $10 \%$ fetal calf serum (FCS, Nutricell) and $1 \%$ penicillin/streptomycin (PS, Hyclone) at $37^{\circ} \mathrm{C}$ in an atmosphere with $5 \% \mathrm{CO}_{2}$. The cells were cultured until $80 \%$ confluence before cytotoxicity assay.

\subsection{Cytotoxicity assay}

The modified Mosmann method was used ${ }^{16}$. Extracts of the tested materials (MD and ND) were obtained by incubating them in Ham's F-12 medium containing 10\% FCS at a proportion of $0.2 \mathrm{~g} . \mathrm{mL}^{-1}$ medium for 48 hours at $5 \% \mathrm{CO} 2$ and $37{ }^{\circ} \mathrm{C}$. This method is in accordance with the standards for evaluation of biomedical devices ${ }^{15}$.

For the indirect cytotoxicity assay, Vero cell suspensions $\left(3 \times 10^{6} \mathrm{cells} / \mathrm{mL}\right)$ were inoculated into a $96-$ well cell culture plate $(\mathrm{n}=5)$ and incubated at $37^{\circ} \mathrm{C}$ for 24 hours. After this, the culture medium was replaced by the extract obtained from the tested materials, and the cells were maintained under these conditions for 24 hours. Ham's F-12 medium with $0.5 \%$ phenol was used as the positive control toxicity (PCT) and polystyrene extract as the negative control toxicity (NCT) in both tests.

After incubation, the medium was removed and the wells were washed with $200 \mu$ L PBS. Next, $200 \mu$ L of Ham's F12 medium with $10 \mathrm{mM}$ of Hepes buffer and $50 \mu \mathrm{L}$ of thiazolyl blue tetrazolium bromide solution (MTT, Sigma) were added, and the plate was incubated in darkness for 4 hours at $37^{\circ} \mathrm{C}$. After that, the medium with MTT was removed, and $200 \mu \mathrm{L}$ of dimethyl sulphoxide (DMSO) was added. The absorbance curve was determined in a microplate reader (Bio-Rad 550 microplate spectrophotometer) at $\lambda=540 \mathrm{~nm}$.
Commercial software (Microcal TM Origin ${ }^{\oplus}$ version 6.0) was used for statistical calculation. Student's t-test was employed for assessing statistical differences between each sample and the NCT and PCT, while the one-way analysis of variance (ANOVA) was employed for assessing statistical differences between all samples. $\mathrm{P}<0.05$ was considered statistically significant.

\subsection{Scanning electron microscopy of cell morphology}

The vero cells $\left(3 \times 10^{6} \mathrm{cell} / \mathrm{mL}^{-1}\right)$ were inoculated in $100 \mu \mathrm{L}$ of Ham's F12 medium supplemented with $10 \%$ FCS in a 96-well plate containing the MD and ND and incubated at $37{ }^{\circ} \mathrm{C}$ in $5 \%$ of $\mathrm{CO}_{2}$ for 24 hours. After this incubation time the $\mathrm{MD}$ and $\mathrm{ND}$ were fixed in $2.5 \%$ paraphormaldehyde (Sigma) and 2.5\% glutaraldehyde (Sigma), the samples were post-fixed in a $1 \%$ solution of osmium tetroxide (Sigma) for 1 hour at room temperature in darkness, washed in distilled water, dehydrated in ethanol, critical-point dried in $\mathrm{CO}_{2}$ (Balzers, CDT 030), coated with gold in a sputter coater (Balzers CTD 050) and viewed with electron microscopy (JEOL 5800).

\subsection{Cytochemical analysis}

The Vero cells were cultivated in contact with MD and ND. A $3 \times 10^{6}$ cell $/ \mathrm{mL}$ in Ham F-10 medium with $10 \%$ FCS cell suspension was inoculated into the materials, and the plate was cultivated for 24 hours at $37^{\circ} \mathrm{C}$. After this, the cells were fixed in Karnovisky (4\% paraformaldehyde $2.5 \%$ grutaraldehyde in $0.2 \mathrm{M}$ phosphate buffer, $\mathrm{pH} 7.2$ ) for 24 hours and stained with toluidine blue (TB) at $\mathrm{pH} 4.0$ to detect nucleic and glycosaminoglycan acids.

\section{Results}

\subsection{Characterization of the microcrystalline and nanocrystalline diamond}

The evaluation by SEM demonstrated that the surface of MD and ND are different. The MD surface was formed by triangular shaped grains and the ND surface had a cauliflower-like aspect (Figure 1a, b).

The ND Raman spectra showed spectrum typically of the nanocrystalline diamond CVD doped with hydrogen and argon due peak superior $1332 \mathrm{~cm}^{-1}$. As seen in Figure 2a, it is evident the diamond peak at $1335 \mathrm{~cm}^{-1}$ and other features characteristic of small structured diamond grains (including nanograins) for samples of ND prepared by Hot-Filament CVD. The Raman spectrum of MD demonstrated one peak in $1331,6 \mathrm{~cm}^{-1}$ in Figure $2 \mathrm{~b}$, which indicates high purity of this diamond evidenced by the absence of other peaks.

Figure 3 demonstrates a typical 3-D AFM image of the ND surface with several aligned triangular features, are in fact image artifacts due to the pyramidal shape of the probe tip. The average roughness of the ND sample, based on three $20 \times 20 \mu \mathrm{m}^{2}$ scanned areas, was calculated as $455 \mathrm{~nm}$. Concerning the MD sample it was not possible to obtain images and roughness measurements as it presented a peak-valley height beyond the resolution of the equipment used $(\sim 8 \mu \mathrm{m})$. 


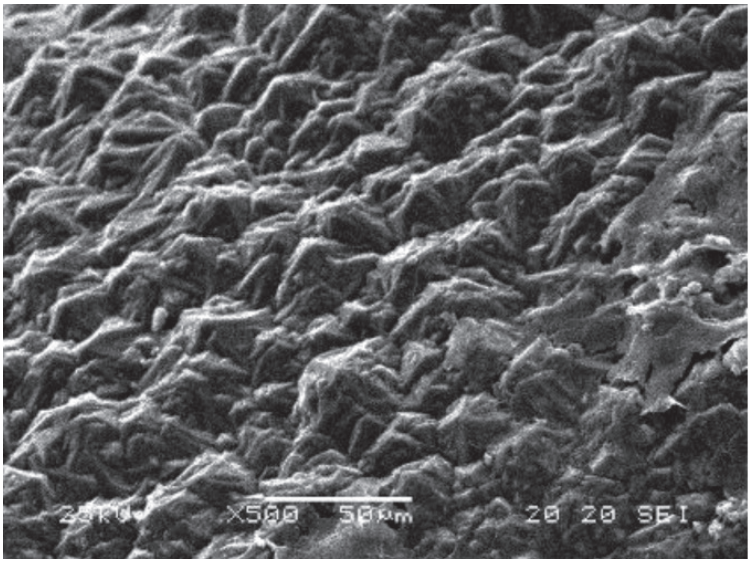

(a)

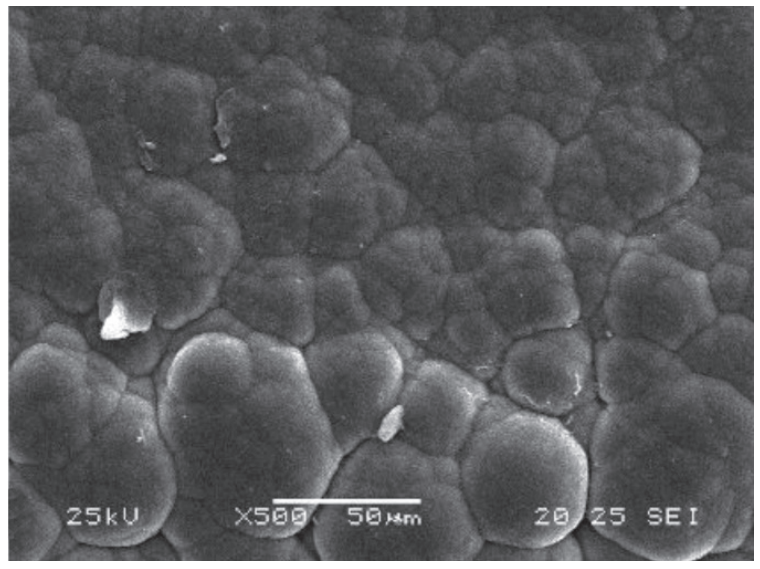

(b)

Figure 1. SEM micrographs of the topography of: a) Microcrystalline Diamond surface was formed by triangular shaped grains and b) Nanocrystalline Diamond surface had a cauliflower-like aspect. Scale bar $=50 \mu \mathrm{m}$ and b).

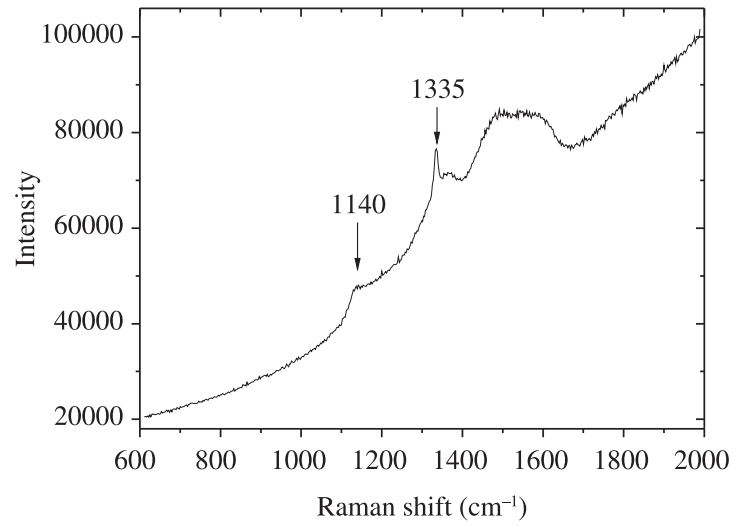

(a)

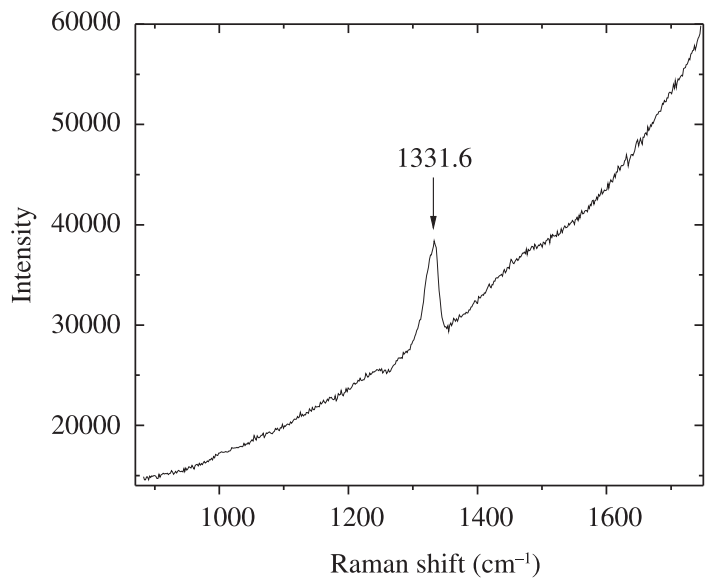

(b)

Figure 2. Raman spectrum of a) Nanocrystalline Diamond and b) Microcrystalline Diamond.

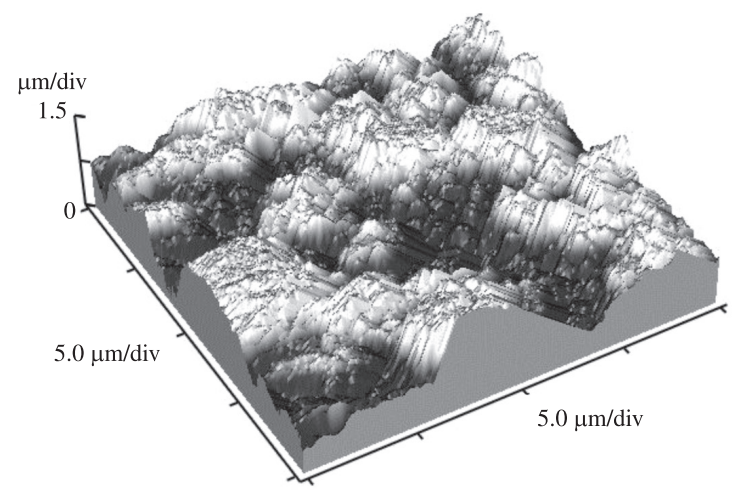

Figure 3. Surface morphology of the Nanocrystalline Diamond sample (3-D imaging with tip artifacts).

\subsection{Cytotoxicity assay}

The results of the cytotoxicity of Vero cells by MTT assay against samples of MD and ND were similar to the results obtained for NCT (Figure 4). According to the Student's t-test, there were statistically significant differences $(* \mathrm{p}<0.05)$ between the readings obtained for all samples and those obtained for PCT.

\subsection{Scanning electron microscopy of cell morphology}

Through SEM it was possible to observe after 24 hours of culture, that cells had adhered well and spread on the substrate, indicating good interaction between the fibroblasts and the surface of MD (Figure 5a). The formation of a thin cell layer was also identified, formed from the cell-cell union initiating the stage of cell confluence, which demonstrates the proper development of fibroblasts (Figure 5b).

In ND it was observed that after 24 hours of culture the formation of a thick cell layer (Figure 5c) was identified 
and, in some regions it was possible to observe even the synthesis of fibrous matrix (Figure 5d). Upon analyzing the images obtained by SEM the MD and ND demonstrated a good cell interaction with the substrate's surface.

\subsection{Cytochemical analysis}

The images obtained in the cytochemical analysis presented appropriate standard. It was observed that cells cultured in the conditions of NCT presented a semi confluent

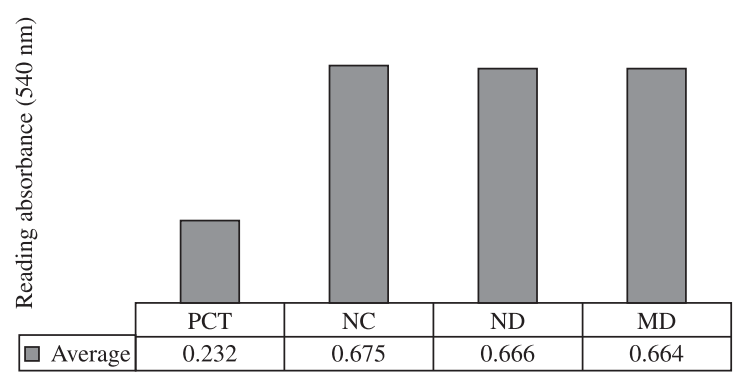

Samples

Figure 4. Indirect cytotoxicity assay of Microcrystalline and Nanocrystalline Diamond with Vero cells. There are no statistically significant differences $(\mathrm{p}>0.05)$ between the samples and the negative control of toxicity (NCT).

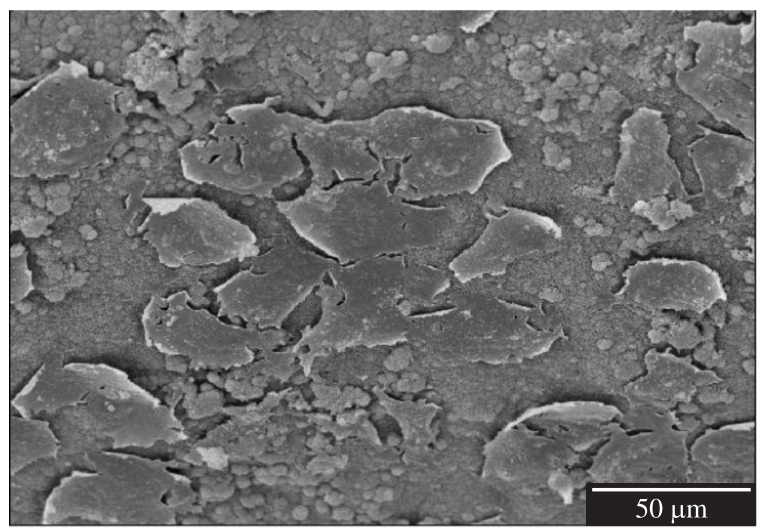

(a)

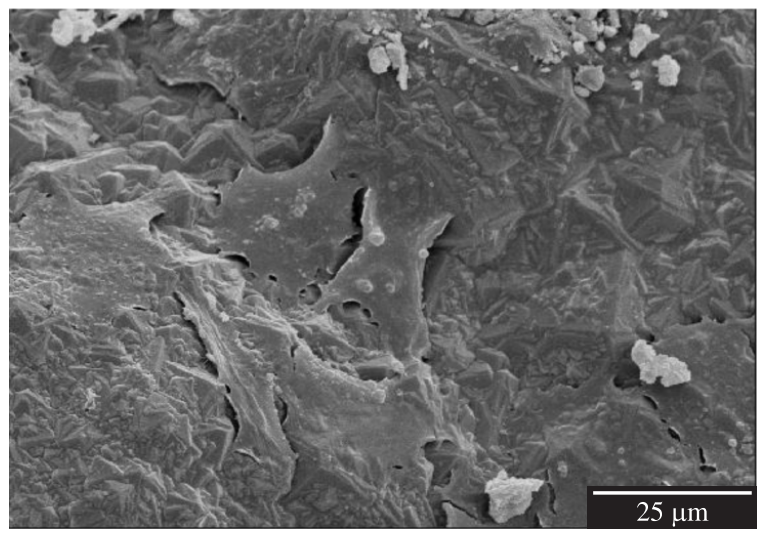

(c) cellular monolayer with mild basophilia at nuclear and cytoplasmic levels. The PCT cells had numerous points of degenerated cells with cellular debris and fragments. The cells cultured in the presence of MD and ND demonstrated a similar pattern to the NCT (Figure 6). Comparing the PCT and NCT to the other experimental situations, we found no signs of toxicity through cytochemical analysis.

\section{Discussion}

The introduction of an implant produces a local inflammatory reaction in the receptor tissue which depends on several factors such as the surgery, the type of tissue and the physic-chemical and geometric characteristics of the implant. The intensity of this reaction can even determine the over life of the implant and its integration during the long term ${ }^{1}$.

The in vitro tests represent a valid method to specifically analyze the tolerance and cell proliferation although they do not mimic all the events that occur when an implant is placed in the living organism ${ }^{17}$. Moreover, this kind of assay provides faster results and with less cost, when compared to evaluations in vivo. In this study the culture of fibroblasts was chosen because these cells are present in the initial phase of the scarring process and the integration of the implant to the tissue $8,18,19$.

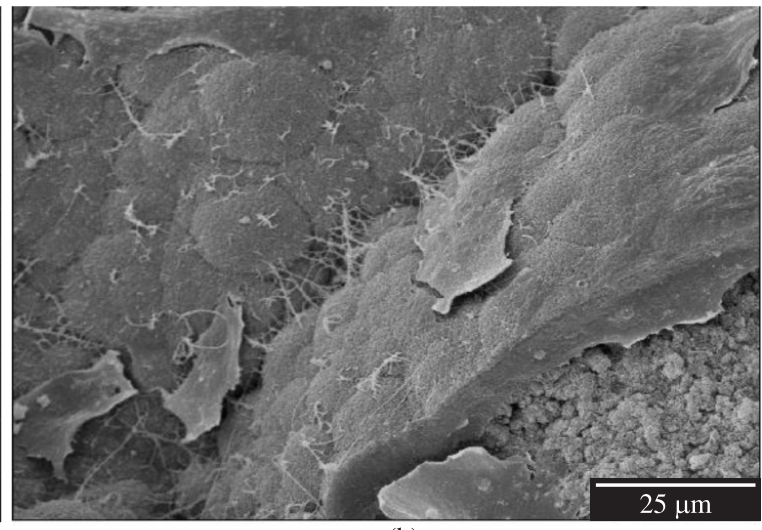

(b)

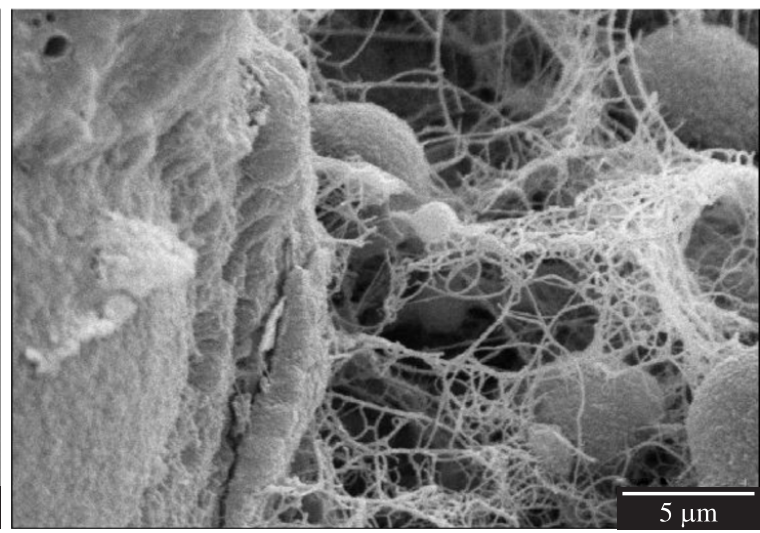

(d)

Figure 5. SEM micrographs cells on the MD after 24 hours of culture was observed: a) cell adhesion on the substrate; b) beginning of cell confluence phase. SEM cells on the ND after 24 hours of culture was observed: c) thick layer formation, intense cell confluence and d) synthesis of fibrous matrix. 
The two compositions of diamond CVD, as assessed in cytotoxicity tests, were considered non-toxic. There was no change in the behavior of adhesion and the cell viability after contact of the culture means with the tubes of ND and MD. Furthermore, through the cytochemical analysis, the ND and MD did not interfere in cellular metabolism, since the used cells continued synthesizing protein and glycosaminoglycans, indicated by the presence of basophil

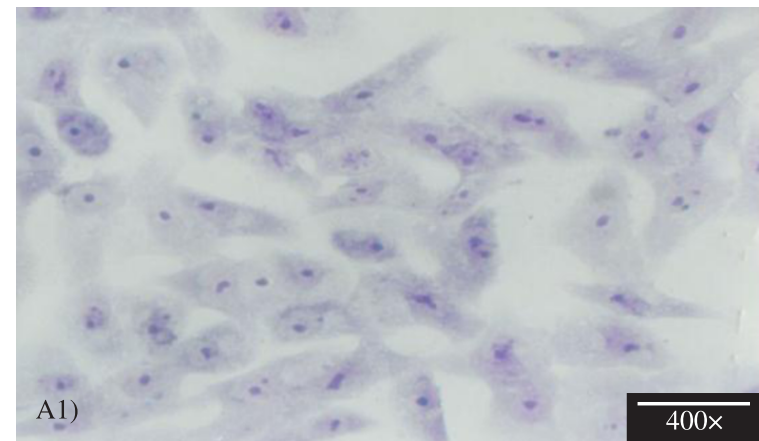

A2)

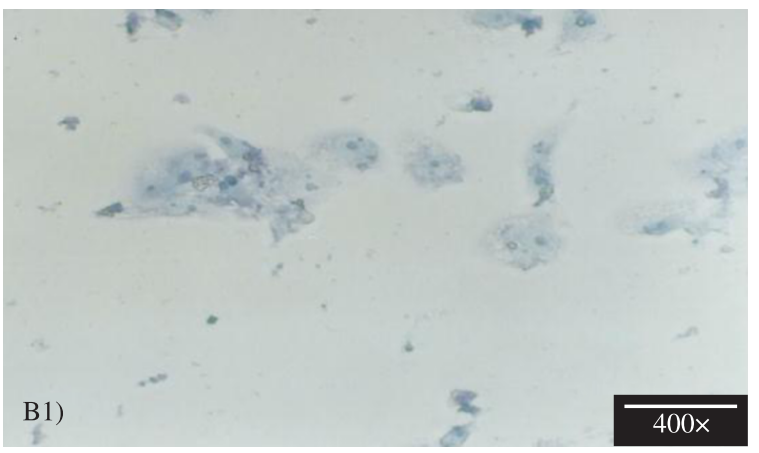

B2) cells stained with TB; the color for nucleic acids and glycosaminoglycans ${ }^{20-22}$. In addition it was observed that the XP, at $\mathrm{pH} 2.5$, stained total proteins, confirming the data obtained with the $\mathrm{TB}^{20,21}$.

The viability of the cells were observed in two samples of the diamond, being more intense in samples of ND. This behavior is similar to the diamond-like carbon ${ }^{23}$. However, there was a synthesis of stringy elements, like the
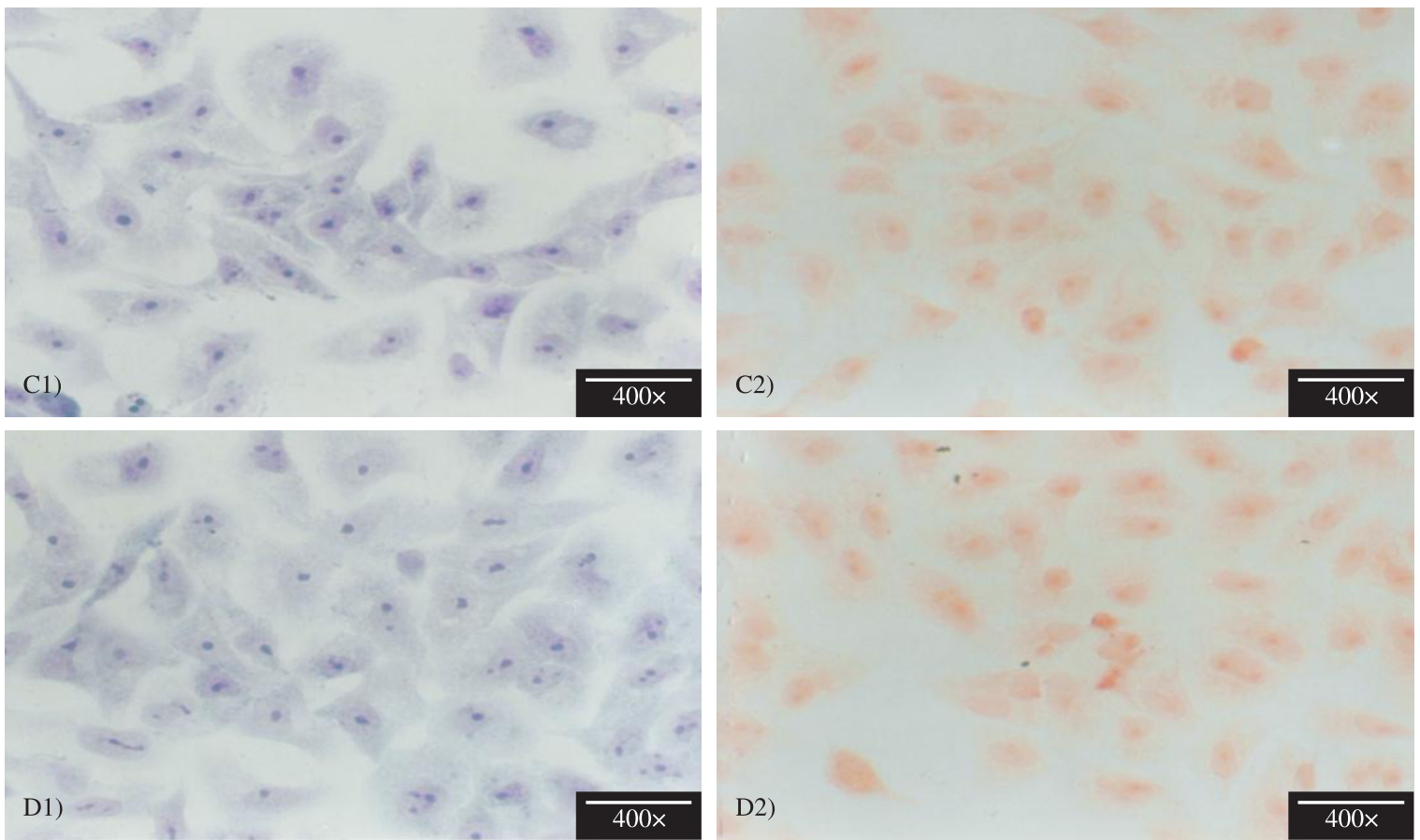

Figure 6. Cytochemical analysis of fibroblastic cells cultured in different experimental conditions: a) NCT; b) PCT; c) MD; d) ND. From a1 to $\mathrm{d} 1$ staining with TB. From a2 to d2 staining with XP. 
extracellular matrix around the tubes of ND, which suggests according to relevant literature, that there is better interaction of this material with the cells ${ }^{24-26}$.

It is interesting to note how the chemical composition of the two types of diamond CVD are identical; the factor that could have influenced that different response cell could be surface finishing of MD (formed by triangular shaped grains) and ND (cauliflower-like surface aspect). The surface roughness of the samples was estimated by AFM. The average value obtained for the ND samples $(455 \mathrm{~nm})$ approaches that of the roughest samples used by Kalbacova $^{27}$. As it was impossible to measure the roughness of MD samples, because their peak-valley height was beyond the resolution of the equipment, it can only be affirmed that their roughness was above $8 \mu \mathrm{m}$. As the two forms of CVD diamond used had similar chemical composition, the surface finishing should be the main factor of ND influencing more strongly the proliferation of fibroblasts even with production of elements of extracellular matrix.

The initial stages of adhesion, spreading and interaction of cells with the implant are influenced by the physicochemical characteristics of the surface of the implant in contact with the receptor tissue. The adhesion phase happens rapidly through physical and chemical connections between the cells and the implant, involving ionic forces and van der Walls forces. The scattering phase is longer and depends on the presence of molecules to link the extracellular matrix proteins such as transmembrane (integrins and cadherins) and the cytoskeleton proteins that interact to induce the signal of transduction, promoting the action of transcription factors and gene expression that determines the quality of cellular interaction ${ }^{1,8,24,25,28-31}$.

Numerous studies have assessed the influence of roughness of materials on the initial cellular response to adhesion and spreading. Eisenbarth et al. ${ }^{28}$ evaluated the adhesion of fibroblasts on Ti6Al4V alloy with different degrees of roughness. After two days of cell incubation higher adherence was observed on the rough surfaces.
Deligianni et al. ${ }^{29}$ observed a higher concentration of bone marrow cells adhered on Ti6Al4V alloy with high roughness indicating a significant influence of the materials surface in the response of bone cells.

Anselme ${ }^{30}$ reported that cultures of osteoblast cells preferably adhere to surfaces with roughness relatively high. These results have been cited previously by Curtis ${ }^{31}$. It is therefore suggested that the different performances of the diamonds should studied here. Yet this differentiated performance can undoubtedly assist in indicating the use of one or the other as an orthopedic implant. Clinical situations that demand greater cell proliferation such as the filling of bone cavities or cartilaginous replacement can best be assisted with the use of ND. Furthermore, situations where this proliferation is undesirable, as in guiding the growth of nerve fibers, the MD maybe better indicated. The evaluation in vivo is now a crucial step in the continuation of this study.

\section{Conclusion}

The cytotoxicity tests performed with fibroblasts way demonstrated that the two compositions of diamond CVD known as MD and ND are not toxic because they had the same performance as NCT. However, the diamond ND with an average surface roughness of $455 \mathrm{~nm}$ stimulated the proliferation of fibroblasts more significantly than $\mathrm{MD}$, which suggests that the former could be suitable for situations that demand tissue proliferation, whereas the later would be better suited to situations where this proliferation is undesirable.

\section{Acknowledgements}

We would like to thank CNPq, FAPESP, INCTBIOFABRIS and National Laboratory of Synchrotron Light - LNLS, Brazil. The authors thank the Department of Applied Physics, Institute of Physics "Gleb Wataghin", University of Campinas, for atomic force microscopy imaging.

\section{References}

1. Anselme K. Osteoblast adhesion on biomaterials. Biomateirals. 2000; 21:667-681. http://dx.doi.org/10.1016/ S0142-9612(99)00242-2

2. Evans EJ and Thomas IT. The in vitro toxicity of cobalt-chrome-molybdenum alloy and its constituent metals. Biomaterials. 1986; 7:25-29. http://dx.doi. org/10.1016/0142-9612(86)90084-0

3. Pennekamp PH, Wimmer MA, Eschbach L, Burian B, Koch P and Kraft CN. Microvasculary reaction of skeletal muscle in Ti-15mMo in comparison to well established in titanium alloys. Journal of Materials Science: Materials in Medicine. 2007; 18:2053-2060. http://dx.doi.org/10.1007/ s10856-007-3116-4

4. Semlitsch MF, Weber H, Streicher RM and Schon R. Joint replacement components made of hot-forged and surface-treated Ti-6Al-7Nb alloy. Biomaterials. 1992; 13:781-788. http:// dx.doi.org/10.1016/0142-9612(92)90018-J
5. Rogers SD, Howie DW, Graves SE, Pearcy MJ and Haynes DR. In vitro human monocyte response to wear particles titanium alloy containing vanadium or niobium. The Journal of Bone \& Joint Surgery. 1997; 79(B):311-315.

6. Wolley PH, Morren R, Andary J, Sud S, Yang S-Y, Mayton $\mathrm{L}$ et al. Inflamatory responses to orthopaedic biomaterials in the murine air pouch. Biomaterials. 2002; 23(2):517-523. http:// dx.doi.org/10.1016/S0142-9612(01)00134-X

7. Evans EJ. Cell damage in vitro following direct contact with fine particles of titanium, titanium alloy and cobalt-chromemolybdenum alloy. Biomaterials. 1994; 9:713-717. http:// dx.doi.org/10.1016/0142-9612(94)90170-8

8. Bordji K, Jouzeau JY, Mainard D, Payan E, Netter P, Rie $\mathrm{KT}$ et al. Cytocompatibility of Ti-6Al-4Va and Ti-5Al-2.5Fe alloys accordind three surface, using human fibroblasts and osteoblasts. Biomaterials. 1996; 17:929-940. http://dx.doi. org/10.1016/0142-9612(96)83289-3 
9. Hallab NJ, Mikecz K and Jacobs JJ. The triple assay technique for the evaluation of metal induced, delayed-type hypersensitivity responses in patient with or receiving total joint arthroplasty. Journal of Biomedical Materials Research. 2000; 53(5):480-489. http://dx.doi.org/10.1002/10 97-4636(200009)53:5\%3C480::AID-JBM6\%3E3.0.CO;2-B

10. Sun ZL, Wataha JC and Hanks CT. Ti and Co effects on ROS 17/2.8 osteoblastic-like cell metabolism in vitro. Journal of Dental Research. 1993; 72: 390-397.

11. Merrit K and Rodrigo JJ. Imune response to synthetic materials. Sensitization of patients receiving orthopaedic implants. Clinical Orthopaedics and Related Research.1996; 326:71-79.

12. Lewis CG and Sunderman FW. Metal carcinogenesis in total joint arthroplasty. Animal model. Clinical Orthopaedics and Related Research. 1996; 329:S264-8. http://dx.doi. org/10.1097/00003086-199608001-00023

13. Angus JC and Hayman CC. Low pressure, metastable growth of diamond and diamondlike phases. Science. 1998; 241:913-919. http://dx.doi.org/10.1126/science.241.4868.913

14. Trava-Airold VJ, Corat EJ, Leite NF, Nono MC, Ferreira NG and Baranauskas V. CVD diamond burrs development and applications. Diamond and Related Materials. 1996; 5:857-860. http://dx.doi.org/10.1016/0925-9635(95)00516-1

15. International Organization for Standardization - ISO. ISO 10993-5 (E): Biological evaluation of medical devices -Tests for cytotoxicity: in vitro methods. International Standart; 1992. part 5.

16. Mossman TJ. Rapid colorimetric assay for cellular growth and survival: Application to proliferation and cytotoxicity assays. Journal of Immunological Methods. 1983; 65:55-63. http:// dx.doi.org/10.1016/0022-1759(83)90303-4

17. Ziats NP, Miller KM and Anderson JM. In vitro and in vivo interactions of cells with biomaterials. Biomaterials. 1988; 9 (1):5-13. http://dx.doi.org/10.1016/0142-9612(88)90063-4

18. Coelho MJ, Cabral AT and Fernandes MH. Human bone cell cultures in biocompatibility testing. Part I: osteoblast differentiation of serrialy passaged human bone marrow cells cultured in MEM and in DMEM. Biomaterials. 2000; 21:1087-1094. http://dx.doi.org/10.1016/ S0142-9612(99)00284-7

19. Coelho MJ and Fernandes MH. Human bone cell cultures in biocompatibility testing. Part II: effect of acid ascorbic, glycerophosphate and dexamethasone on osteoblast differentiation. Biomaterials. 2000; 21:1095-1102. http:// dx.doi.org/10.1016/S0142-9612(99)00192-1

20. Lison L. Histochemie et Cytochemie Animales - Principles et Methodes. 3th ed. Paris: Gauthier Villars France; 1960. p. 285.
21. Mello MLS. Cytochemistry of DNA, RNA and nuclear proteins. Brazilian Journal of Genetics. 1997; 20: 257-264.

22. Stabellini G, Calastrini C, Scapoli L, Locci P, De Mattei M, Dellavia $\mathrm{C}$ et al. The effect of polyamines and dialysate fluid on extracellular matrix synthesis in Vero cell cultures. Journal of Nephrology. 2002; 15:539-546.

23. Uzumaki ET, Lambert CS, Bonugli LO, Santos AR and Zavaglia CAC. Morphology of fibroblastic cells cultured on diamond-like carbon coatings produced by plasma immersion using AFM and SEM. Key Engineering Materials. 2006; 309:713-716. http:// dx.doi.org/10.4028/www.scientific.net/KEM.309-311.713

24. Santos Junior AR, Barbanti SH, Duek EAR, Dolder H, Wada RS and Wada MLF. Vero cell growth and diferentiation on poly (1-lactic acid) membranes of diferents diameters. Artificial Organs. 2001; 25:7-13. http://dx.doi.org/10.1046/ j.1525-1594.2001.025001007.x

25. Santos Junior AR, Ferreira BMP, Duek EAR, Dolder H, Wada RS and Wada MLF. Differentiation pattern of vero cells cultured on poly (1-lactic acid)/poly (hidroxyvalerate) blends. Artificial Organs. 2004; 28:381-389. http://dx.doi. org/10.1111/j.1525-1594.2004.47199.x

26. Santos Junior AR, Dolder H and Wada MLF. Dexamethasone and fetal calf serum effects in differentiation of Vero cells cultured on type I collagen gel. Journal of Submicroscopic Cytology and Pathology. 2003; 35:35-42.

27. Kalbacova M, Rezek B, Baresova V, Wolf-Brandstetter C and Kromba A. Nanoscale topography of nanocrystalline diamonds promotes differentiation of osteoblasts. Acta Biomaterialia. 2009; 5:3076-3085. http://dx.doi.org/10.1016/j. actbio.2009.04.020

28. Eisenbarth E, Meyle J, Nachtigall W and Breme J. Influence of the surface structure of titanium materials on the adhesion of fibroblasts. Biomaterials. 1996; 17:1399-1403. http://dx.doi. org/10.1016/0142-9612(96)87281-4

29. Deligianni DD, Katasla N, Ladas S, Sotiropoulou D, Amedee $\mathrm{J}$ and Missirlis YF. Effects of surface roughness of the titanium alloy Ti-6Al-4V on bone marrow cell response and on protein adsorption. Biomaterials. 2001; 22:1241-1251. http://dx.doi. org/10.1016/S0142-9612(00)00274-X

30. Anselme K, Bigerelle M and Noel B. Effect of grooved titanium substratum on human osteoblastic cell growth. Journal of Biomedical Materials Research. 2002; 60: 529-540. http:// dx.doi.org/10.1002/jbm.10101

31. Curtis A and Wilknson C. Topographical control of cells. Biomaterials 1997; 18:1573-1583. http://dx.doi.org/10.1016/ S0142-9612(97)00144-0 